\title{
Impacts of Environmental Change on Fish Production in Egypt and Nigeria: Technical Characteristics and Practice
}

\author{
M. L. Adeleke, D. Al-Kenawy, A. M. Nasr-Allah, M. Dickson, and \\ Ayal Desalegn
}

\section{Contents}

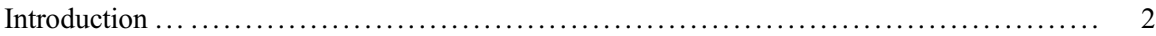



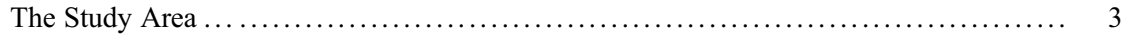



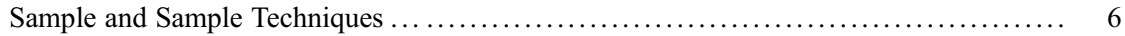

Data Collection Tools .................................................. 6

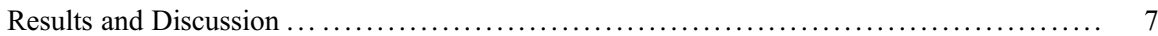

Socioeconomic Characteristics of Fish Farmers in Egypt and Nigeria $\ldots \ldots \ldots \ldots \ldots \ldots \ldots \quad 7$

Technical Characteristics of Fish Farming System and Operation in Egypt and Nigeria ... 8

Environmental Changes Impacts on Fish Production in Egypt and Nigeria ............ 11

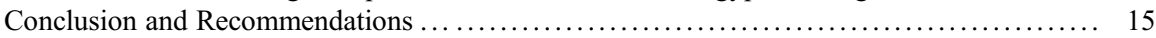

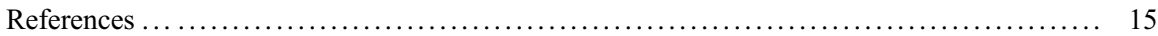

\section{Abstract}

A survey approach was applied to examine the technical characteristics of fish farming practice in Egypt and Nigeria. Critical issues such as floods and other

This chapter was previously published non-open access with exclusive rights reserved by the Publisher. It has been changed retrospectively to open access under a CC BY 4.0 license and the copyright holder is "The Author(s)". For further details, please see the license information at the end of the chapter.

\section{L. Adeleke (西)}

Department of Fisheries and Aquaculture Technology, The Federal University of Technology, Akure, Akure, Nigeria

e-mail: mladeleke@futa.edu.ng; mosunmolalydia@yahoo.com

D. Al-Kenawy · A. M. Nasr-Allah · M. Dickson

WorldFish, Abbassa, Abou-Hammad, Sharkia, Egypt

\footnotetext{
A. Desalegn

College of Development Studies, Center for Food Security Studies, Addis Ababa University, Addis Ababa, Ethiopia
} 
vices were considered in bringing out the inference and level of aquaculture in both countries. Multistage sampling technique was used to select the study area and the number of respondents. Both primary and secondary data were used in the analysis. Eighty fish farmers were randomly selected from each of the country, making a total of 160 respondents. The socioeconomic characteristics revealed that aquaculture is an antique venture in Africa with Egypt taking the lead, i.e., $99 \%$ of the respondents practice in large-scales production of more than 11 Fadden/acre per, and $100 \%$ males depend mainly on agricultural drainage water for their earthen ponds. Ninety-eight percent cultured tilapia (Oreochromis niloticus) which was believed to have originated from the Nile River. In terms of financial performance and partial economic analysis, tilapia production commands more sales in Egypt, while catfish (Clarias) production is seen as a promising venture in Nigeria. The fish farmers have various perceptions and reactions toward environmental changes factors such as cost of labor/manpower and inputs, poor water quality, and fish extension services, and climate change impedes aquaculture development in the countries. To achieve the scale of aquaculture expansion as observed in Asian and other developed part of the world, efforts should be geared toward continental and regional integration in order to encourage aquaculture practices in Nigeria and other parts of Africa. More so, government intervention and incentives should be paramount in Egypt to reduce the excessive exploitation of the private input suppliers.

\section{Keywords}

Technical $\cdot$ Environmental $\cdot$ Fadden $\cdot$ Tilapia and catfish

\section{Introduction}

Aquaculture is an organized process in which the cultivation of aquatic animals and plants in fresh, brackish, and marine water is made, to increase fish production above the level that would be produced naturally (FAO 2016). Fish is the most-traded food commodities worldwide; more than 3.1 billion people depend on it for their average per capita intake of animal protein which is about $20 \%$. Aquaculture has increased the world per capita fish supply to $20 \mathrm{~kg}$ in 2014 (FAO 2016). Global fish forecast model predicts that the share percentage of capture fisheries is expected to fall by half in 2030 compared to the $60 \%$ global production in 2011 after growing only by 2.8 million. Aquaculture is expected to grow by 30 million tons over this same period. In terms of food fish production, the model predicts that aquaculture will contribute $62 \%$ of the global supply by 2030 (FAO 2016). The problem of feeding the more than 9 billion people in the world by 2050 in the context of climate change and uncertainty (World Bank 2013) will be rightly addressed if improved aquaculture management is adhered.

Aquaculture seems to be multilocational and isolated. The Egyptians were probably the first in the world to culture fish as far back as 2500 B.C. from Japanese Resource Council, Science and Technology Agency as cited in Jhingran (1987). 
Aquaculture production in Egypt far exceeds that of the rest of the other Africa countries. It is a 2.2 billion USD in 2015. Egyptian aquaculture currently provides almost $79 \%$ of the country's fish needs, with almost all the output coming from small- and medium-sized privately owned farms (GAINS 2015).

Aquaculture was introduced into Nigeria in the 1950s. Recently, it is one of the fastest growing agricultural enterprises in the country. It impacted the nation's economy in terms of contributing over 1 million metric tons to Gross Domestic Product (GDP). It is best alternatives to meet protein demand; it is a business with brighter opportunities. Despite the fact that aquaculture is an age-old practice in some regions of the world, it is relatively new in most African countries and is significant to the economic, livelihood, and nutritional welfare of the populace. From all indications, Egypt has the largest aquaculture industry in Africa (Sumaila et al. 2014).

Therefore, the research questions, what are the technical factors to be considered in order to shrink the disparities? And environmental changes impact on fish production in Africa. This paper classically, therefore, examines the technical characteristics of fish farming (Aquaculture) practice and impacts of environmental change on fish production in Egypt and Nigeria. Specifically, the socioeconomics characteristics of the respondents were determined using Kobocollect, fish farming system and operation were examined, and critical issues and institutional framework were considered bearing in mind the fish farmers' awareness on environmental changes.

\section{Methodology}

\section{The Study Area}

Egypt (see Fig. 1) is located between $30^{\circ} 06^{\prime} \mathrm{N}$ and $31^{\circ} 25^{\prime}$ E. Based on the US estimates, the current population of Egypt is 94,660,721 which is equivalent to $1.27 \%$ of the total world population (Worldometers 2017), and the total land area is $995,560 \mathrm{~km}^{2}$ (384,388 sq. mi). The climate is arid where most of the rains fall in the winter months with an average of $2-5 \mathrm{~mm}(0.1-0.2$ in)/year with the exception of the Northern coast which sometimes can be as high as $410 \mathrm{~mm}$ (16.1 in) between the period of October and March (Worldometers 2017). The temperature range from $49.1^{\circ} \mathrm{F}$ to $73.4^{\circ} \mathrm{F}$ in low wind and sometimes average high temperatures vary from $62.6^{\circ} \mathrm{F}$ in wintertime to $89.6^{\circ} \mathrm{F}$ in summertime were recorded.

The Nile is the primary water source of Egypt and provides more than $95 \%$ of all water available to the country. Over 60 million people are connected with the agricultural sector which constitutes $20 \%$ of GDP and consumes about $80 \%$ of the water budget. Aquaculture in Egypt is supported by water from irrigated agriculture and lakes such as lakes Burullus, Manzala, and Edku all located in Egypt.

Nigeria (see Fig. 2) lies exclusively within the tropical zone in West Africa. It borders with the Republic of Benin in the west, Chad and Cameroon in the East, and Niger in the North. The current population is $190,423,532$ which is equivalent to 


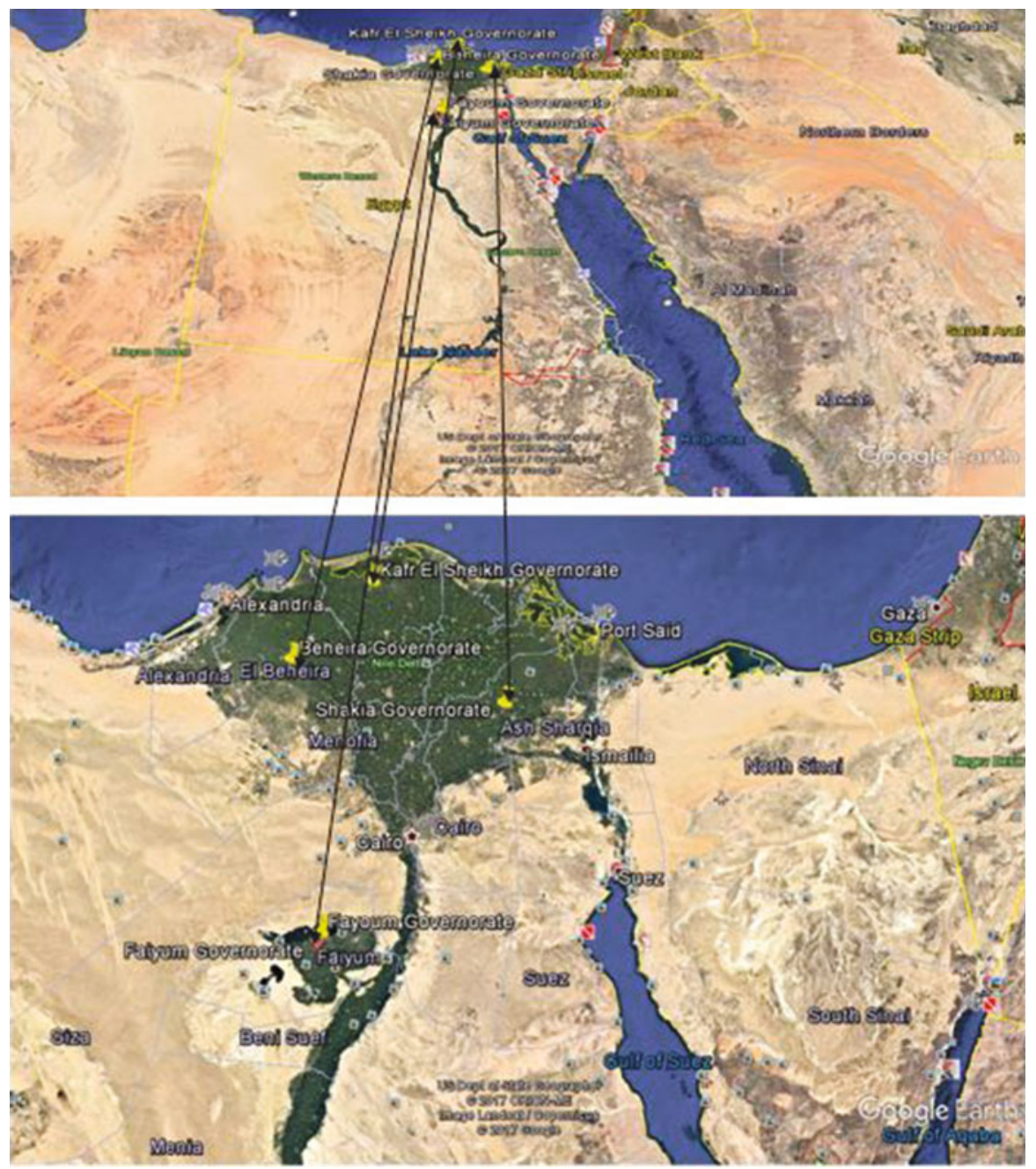

Fig. 1 Google Earth Map showing the study area in Egypt. (Source: Authors creation, 2017)

$2.55 \%$ of the total world population and ranked 7 th in the list (Worldometers 2017). The total land area is $910,802 \mathrm{~km}^{2}\left(351,662\right.$ sq. mi) with $9^{\circ} 82^{\prime} 00^{\prime \prime} \mathrm{N} ; 8^{\circ} 67^{\prime} 530^{\prime \prime} \mathrm{E}$ coordinates (see Fig. 2). The northeast and southwest winds are the two principal wind currents that make Nigeria to be distinguished with two distinct seasons: a wet season from April to October, with generally lower temperatures, cloudy and rainy weather upshot of the southwest wind current. There are wide climatic variations in the country depending on the season and region. Nigeria got her name from the river, Niger River. Nigeria is indeed blessed with marine, brackish, and freshwater in addition to lakes, rivers, deltas, reservoirs, dams, rain, floodplains, inland, and coastal waters to support fisheries and aquaculture in the country. 

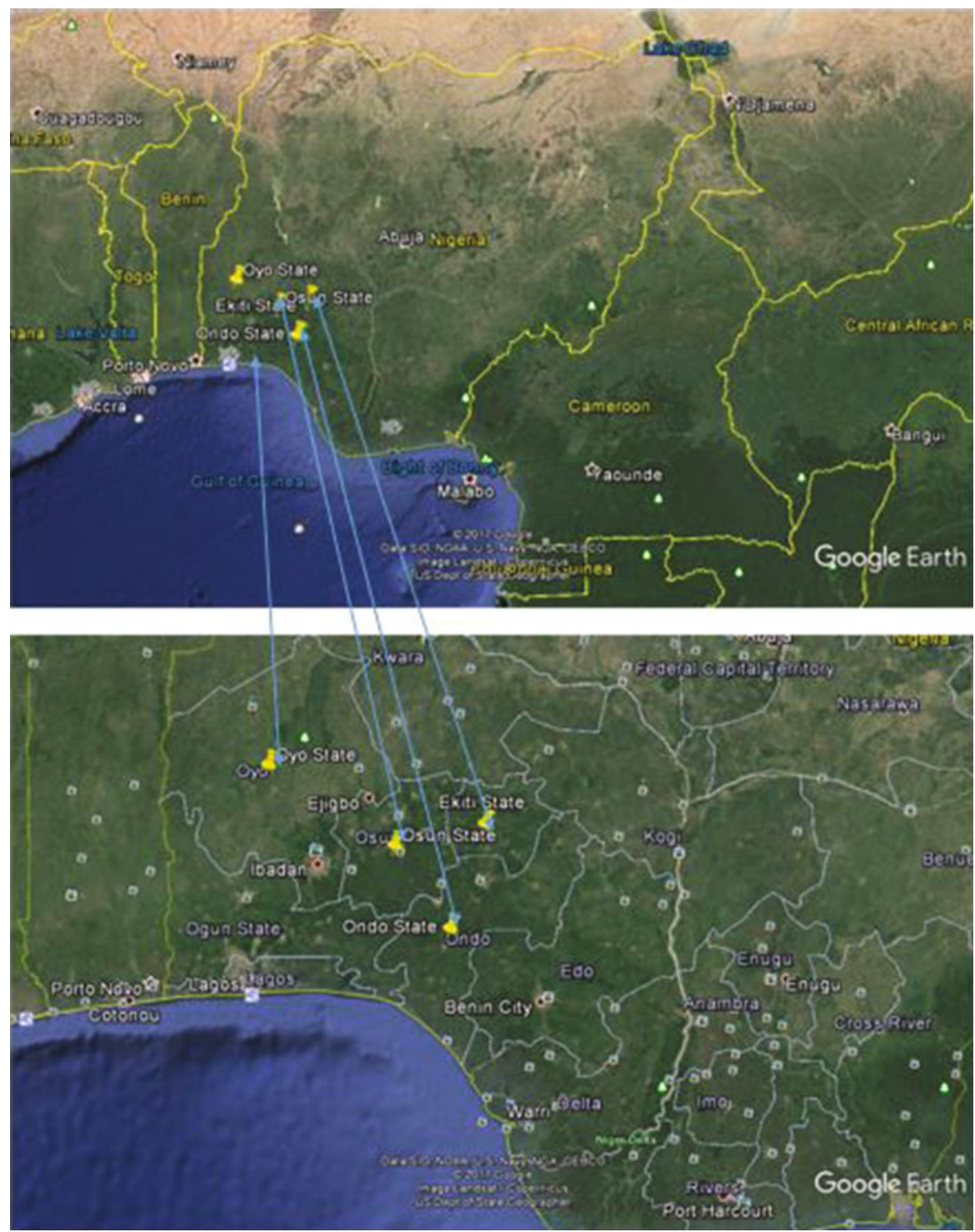

Fig. 2 Google Earth Map showing the study area in Nigeria. (Source: Authors creation, 2017)

\section{The Design}

In this research, explanatory mixed research design was applied to address specific objectives of the research work. The selected research design allows to collect data from different sources using various data collection tools. Quantitative data were collected using semi-structured and open-ended questions from key informants. 
Focus Group Discussion (FGD) checklists were also used to collect data. While, quantitative data was collected using questionnaire survey from the sampled fish farmers households. The questionnaire was used to collect data on the socioeconomic characteristics of the respondents, technical characteristics of the fish farms, the critical issues (water shortage, water quality, floods, and other vices), institutional framework, and respondents' perceptions of the environmental changes. Experienced male (six) and female (six) enumerators were recruited and trained.

\section{Sample and Sample Techniques}

A multistage sample technique was used to select the study area and respondents. Egypt and Nigeria were purposely selected because of the green and blue water-type availability for aquaculture, respectively. In Egypt, Kafr El Sheikh (KFS), Bahera, Shakia, and Port Said Governorates were purposely selected due to their aquaculture practice. Likewise in Nigeria, Ekiti, Ondo, Osun, and Oyo states were selected purposely in southwest of the country. This is because the states are in the same geopolitical zones. In the Egypt and Nigeria sites, a total of 160 fish farmers' households were selected using proportional random sampling method (see Table 1). The data collection was carried out between January and April, 2017, in Egypt and Nigeria.

\section{Data Collection Tools}

Data collections were done by a six paired (male and female) trained enumerators who were trained on the use of Kobocollect and questionnaire administration. Data collections were done using Kobocollect application on the tablets/IPhones; in some cases, structured questionnaires, the completed questionnaire, were later keyed into the Kobocollect. Interview schedule and Focus Group Discussions (FGD) were also employed to get responses from the fish farmers in accordance to the set objectives

Table 1 Distribution of questionnaire survey participants sample fish farmer households

\begin{tabular}{l|l|l|l|l|l|l}
\hline & \multicolumn{5}{|l|}{ Egypt } & \multicolumn{2}{l}{ Nigeria } \\
\cline { 2 - 7 } No. & Site & $\begin{array}{l}\text { Total fish farmer } \\
\text { households }\end{array}$ & $\begin{array}{l}\text { Sample } \\
\text { size }\end{array}$ & Site & $\begin{array}{l}\text { Total fish farmer } \\
\text { households }\end{array}$ & $\begin{array}{l}\text { Sample } \\
\text { size }\end{array}$ \\
\hline 1. & $\begin{array}{l}\text { Kafr El } \\
\text { Sheikh }\end{array}$ & 35 & 35 & $\begin{array}{l}\text { Ekiti } \\
\text { state }\end{array}$ & 20 & 20 \\
\hline 2. & Bahera & 15 & 15 & $\begin{array}{l}\text { Ondo } \\
\text { state }\end{array}$ & 20 & 20 \\
\hline 3. & Shakia & 15 & 15 & $\begin{array}{l}\text { Osun } \\
\text { state }\end{array}$ & 20 & 20 \\
\hline 4. & Port Said & 15 & 15 & $\begin{array}{l}\text { Oyo } \\
\text { state }\end{array}$ & 20 & 20 \\
\hline
\end{tabular}

Source: Authors Computed Field Survey 
and scope of the research work. KoboToolBar supported the participants to collect data online and offline especially during a logistical constraint. It gives room for backed up into secure servers. The questionnaire with similar content was prepared in two languages: English and Arabic. The English version was administered in Nigeria, while the Arabic version was administered on the respondents in Egypt.

\section{Results and Discussion}

\section{Socioeconomic Characteristics of Fish Farmers in Egypt and Nigeria}

The results of the Kobocollect analysis of the fish farmers' socioeconomic characteristics are presented in Table 2.

Gender: refers to the socially built characteristics such as norms, roles, and relationship of and between groups of women and men (male or female). Like age classification, it also varies from society to society. The result showed that the percentage of male fish farmers in Nigeria was $93 \%$ and that of the female was 7\%. Though, this chapter revealed there was no female fish farmers in Egypt. This suggests that females might have been involved in other activities apart from fishing. The result also revealed that more males were in aquaculture than the females in both countries. This might be due to the fact that aquaculture production is more of manual labor/blue-collar job in which more physical energy are required. They are also likely to be involved in other fish farming activities like processing and

Table 2 Socioeconomics characteristics of the fish farmers in Egypt and Nigeria

\begin{tabular}{l|l|l}
\hline \multirow{2}{*}{ Category or variable } & Egypt & Nigeria \\
\hline Gender & Frequency (\%) & Frequency (\%) \\
\hline Male & & \\
\hline Female & $79(100.0)$ & $74(92.5)$ \\
\hline Total & - & $6(7.5)$ \\
\hline Fish farm as main occupation & $79(100.0)$ & $80(100.00)$ \\
\hline Yes & & \\
\hline No & $70(88.6)$ & $33(41.25)$ \\
\hline Total & $9(11.4)$ & $47(58.75)$ \\
\hline & $79(100.0)$ & $80(100.00)$ \\
\hline Fish farming experience (years) & Mean \pm S.E. & Mean \pm S.E. \\
\hline Farm distance from residents $(\mathrm{km})$ & $18.6 \pm 1.10$ & $6.46 \pm 1.22$ \\
\hline Number of household & $22.27 \pm 6.41$ & $4.7 \pm 1.07$ \\
\hline Number of children under 18 years & $6.28 \pm 0.34$ & $4.57 \pm 2.83$ \\
\hline Number of adult above 60 years & $2.96 \pm 0.24$ & $1.4 \pm 1.17$ \\
\hline Number of male in the household & $0.19 \pm 0.07$ & $0.41 \pm 0.29$ \\
\hline Number of female in the household & $3.27 \pm 0.19$ & $2.36 \pm 2.46$ \\
\hline Sor A & $3.00 \pm 0.21$ & $2.2 \pm 1.67$ \\
\hline
\end{tabular}

Source: Authors Computed Field Survey 
marketing couple with their home cares which were sometimes uncounted (Adeleke 2013). The result also agrees with the study of Olufayo (2012); Adeleke and Fagbenro (2013) that women participate not only in the traditional fisheries sectors of fish processing and marketing but also in the nontraditional sectors of aquaculture, fisheries research, education, and extension.

Fish farming as main occupation: In Egypt, $89 \%$ of the respondents took fish farming as the main occupation, whereas the rest $(11 \%)$ considered it as their secondary occupation. On the other hand, the result revealed that $41 \%$ of the respondents in Nigeria ranked fish farming as the main occupation, while majority $(59 \%)$ chose it as the secondary occupation; other occupation engaged by the respondents in the study areas were civil servant, trading, carpentry, tailoring, teaching, agribusiness, and driver. This suggests that aquaculture in Nigeria is still at the developmental stage. Aquaculture production in Nigeria at present is fairly insignificant at 5000 tons/year (FAO 2000). FAO estimates that this could be increased to about 650,000 tons. Recent researches showed that aquaculture in Nigeria has potential to contribute to both food security and economic development of the country but is still in a promising business. Despite the fact that aquaculture is an age-old practice in Egypt, it is still contributing immensely to the country's GDP, employment, and food security as it is doing relatively in most countries and is significant to the economic, livelihood, and nutritional welfare of the populace.

\section{Technical Characteristics of Fish Farming System and Operation in Egypt and Nigeria}

Parameters such as scale of operation, types of pond, source of water, access to water, water quality parameters, types of fish produced/cultured species, fish with highest production and demand, venture profitability, continuity, and inputs sources were considered. The results were analyzed and presented accordingly.

Scale of operation and purpose for rearing fish: The study revealed that small-, medium-, and large-scale farming operations were practiced in the study areas (see Table 3). The scale of operations determined the purpose of rearing fish as designated by this study. Small-scale production implies for household consumption; medium-scale production is meant for household consumptions and sales, while large-scale production does mean for fully commercial/industrial/exports. The results revealed that none of the respondents in Egypt practice small-scale fish production; only $1 \%$ of them were operating their farms on medium scale, while 99\% operate more than ten Fadden. This shows that fish production in Egypt is in a large-scale operation.

On the other hand, $63 \% \%$ and $30 \%$ in Nigeria represented those that operate their fish farms on small scale and medium scale, respectively, while only $7 \%$ operated their fish farms on a large scale. The result also revealed that aquaculture in Nigeria is in small scale (93\%) as compared to Egypt. The result indicates that fish farming operation in Nigeria is still at the subsistence level where production is mainly for the 
Table 3 Technical characteristics of fish farming system and operation in Egypt and Nigeria

\begin{tabular}{|c|c|c|}
\hline \multirow[b]{2}{*}{ Indicators } & Egypt & Nigeria \\
\hline & Frequency $(\%)$ & Frequency $(\%)$ \\
\hline \multicolumn{3}{|l|}{ Purpose for rearing fish } \\
\hline Small scale (household) & - & $50(62.5)$ \\
\hline Medium scale (household and sales) & $1(1.3)$ & $24(30.0)$ \\
\hline Large scale (commercial/industrial/exports) & $78(98.7)$ & $6(7.5)$ \\
\hline Total & $79(100)$ & $80(100)$ \\
\hline \multicolumn{3}{|l|}{ Types of pond } \\
\hline Earthen ponds & 78 (98.7) & $70(87.5)$ \\
\hline Others (concrete, plastic, collapsible tanks, vats) & $1(1.3)$ & $10(12.5)$ \\
\hline Total & $79(100)$ & $80(100)$ \\
\hline \multicolumn{3}{|l|}{ Source of water } \\
\hline Stream & - & $29(36.25)$ \\
\hline River & $5(6.3)$ & $9(11.25)$ \\
\hline Groundwater/well/boreholes & - & $28(35.0)$ \\
\hline Rain catchment/reservoirs & - & $16(20.0)$ \\
\hline Lake water & $10(12.7)$ & - \\
\hline Agricultural drainage water & $61(77.7)$ & - \\
\hline Mixed drainage and Nile water & $3(3.8)$ & - \\
\hline Total & $79(100)$ & $80(100)$ \\
\hline \multicolumn{3}{|l|}{ Problems as regards the water source } \\
\hline Yes & $63(79.7)$ & $33(41.25)$ \\
\hline No & $16(20.3)$ & $47(58.75)$ \\
\hline Total & $79(100)$ & $80(100)$ \\
\hline \multicolumn{3}{|l|}{ Have you taken precautionary measures } \\
\hline Yes & $45(57.0)$ & $21(26.25)$ \\
\hline No & $34(43.0)$ & $59(73.75)$ \\
\hline Total & $79(100)$ & $80(100)$ \\
\hline
\end{tabular}

Source: Authors Computed Field Survey

households with little or nothing for the market/sale. This implies that Nigeria will depend on import of fish to meet the demand of the common people.

The result supports that Egypt has achieved the scale of expansion and growth in aquaculture (Adeleke and Matthias 2017). Hence, aquaculture in Egypt is a 2.2 billion USD a year industry and has been supporting the country's GDP in recent years, making it the ninth largest global aquaculture producer in 2012 and by far the largest in Africa and the Middle East (FAO 2016). Efforts should be geared toward encouraging and promoting aquaculture practices in Nigeria in order to meet the demand of the households and consumers. Large-scale production should also be encouraged in order to expand the local and international market.

Types of pond: $99 \%$ of the fish farmers in Egypt cultured their fish in earthen ponds, while in Nigeria, $88 \%$ cultured their fish in earthen ponds. One percent and $12 \%$ of the fish farmers in Egypt and Nigeria, respectively, represent other types of ponds such as concrete, plastics, collapsible, and fiber tanks and vats. The 
results of the study revealed that earthen ponds are commonly used in both countries. The percentages of other types of ponds like plastics or tanks are more in Nigeria (12\%) than in Egypt (1\%). Because of the culture and environment, tilapia is most commonly grown fish species in Egypt. It can do well in earthen ponds where natural food is required; it cannot survive in very low or too high temperature. In contrast in Nigeria, catfish can be raised in an enclosure or tanks where it can thrive, and no artificial aeration is required, but artificial food is required for the survival of the enclosed fish. It implies that ponds type is a very vital parameter to be considered in aquaculture business.

Source of water: the results of the study revealed that fish ponds can get water from various water sources depending on the availability, location, and law. In Egypt, the following water sources and percentages were identified: lake (13\%), river (6\%), agricultural drainage water (78\%), and mixed drainage and Nile (45\%). It was observed that most of the fish farmers relied on agricultural drainage water. The result is not far-fetched from the fact that aquaculture is the last user of water in Egypt because it made used of reused water. According to the water policy in Egypt. On the other hand, the percentages of the sources of water in Nigeria are represented as follows: $36 \%$ stream, $11 \%$ river, $35 \%$ groundwater/boreholes, and $20 \%$ rain catchment/reservoirs. It was observed that in Nigeria, most of the water was freshwater sources; this also determined the type of fish to be cultured.

Apparently Egypt represents a good example of a green aquaculture because $78 \%$ of the fish farmers depend solely on agricultural drainage water while Nigeria is good representation of a blue aquaculture because the water sources were mainly fresh water hence, the type of fish to be cultured. In Egypt, recent research showed that the use of aquaculture drainage water for agriculture is better preferred to the existing practice of agriculture drainage water for aquaculture. The use of aquaculture drainage water is best practice due to its numerous advantages. Aquaculture drainage water contained a lot of nutrients for the crops than the agricultural drainage water which might at the same time not be good for the cultured fish. Efforts should be geared to convince the government in Egypt to pay more attention to the reused of aquaculture drainage water for effective and maximum utilization of water in the country. Eighty percent (80\%) of the fish farmers in Egypt that the source/s of the water to their farms/ponds is/are challenging while only $20 \%$ believe the source/s of water is/are good and not challenging (Table 3). Despite the natural and blue water sources in Nigeria, $41 \%$ believed the water source/s posed a serious problem to their fish farms, while $59 \%$ were comfortable with the water source/s to their fish farms.

In Egypt, the problem that was highlighted and emphasized mainly on water sources was pollution, while in Nigeria, the problem was water shortage as a result of dry season. In Egypt, 57\% of the respondents have taken precautionary measures as regards reducing the effect of pollution on the water source that enters their farms by checking the water qualities, filter the water when pumping, treatment of water and pond, but $43 \%$ are yet to take any precautionary measures. The reason might be due to the fact that they are constrained to the available water source to be used for aquaculture in the country. In Nigeria, $60 \%$ of the fish farmers have alternative source of water such as getting water from other ponds, buying water from water 
tankers, damming of stream water to pump into the pond, boreholes, or well, and reducing stocking density, to their fish farms during dry season in Nigeria, while $40 \%$ of the fish farmers have not taken any precautionary measures. The reason might not be far-fetched from the facts that most of the fish farmers in Nigeria practice on subsistence level, and lack of capital is also a limiting factor from the Focus Group Discussion (FGD). Freshwater is the major water source in Nigeria and there are no restriction as to the use of water in the country, is a great opportunity and advantage for citizens who are willing to practices aquaculture to really venture into it because aquaculture is "no restriction of person."

\section{Environmental Changes Impacts on Fish Production in Egypt and Nigeria}

Table 4 presents the impacts of environmental changes on aquaculture in the study areas. The study revealed that $76 \%$ of the fish farmers in Egypt were aware of the environmental changes and its impacts on aquaculture. From the FGD, the fish farmers highlighted some observed effect of environment change on the fish production in their countries. In Egypt, the following were highlighted: reduction in rain and increase in level of temperature particularly during summer period (July);

Table 4 Environmental changes impacts on fish production in Egypt and Nigeria

\begin{tabular}{l|l|l}
\hline \multirow{2}{*}{ Parameters } & Egypt & Nigeria \\
\cline { 3 - 3 } $\begin{array}{l}\text { Do you have idea of what climate change means } \\
\text { Yes }\end{array}$ & $60(76)$ & Frequency (\%) \\
\hline No & $19(24)$ & $76(95)$ \\
\hline Total & $79(100.0)$ & $4(05)$ \\
\hline Time to first experience the change & \multicolumn{2}{l}{} \\
\hline Value (years) & $46(58.3)$ & \\
\hline $0-5$ & $10(12.7)$ & $38(47.5)$ \\
\hline $6-10$ & $3(3.8)$ & $11(13.8)$ \\
\hline $11-20$ & - & $3(3.8)$ \\
\hline $21-30$ & $20(25.4)$ & $3(3.8)$ \\
\hline 31 and above & $79(100.0)$ & $25(31.3)$ \\
\hline Total & & $80(100.0)$ \\
\hline Means of environmental changes awareness & & \\
\hline Value (source) & $29(36.7)^{\mathrm{a}}$ & $66(82.5)^{\mathrm{a}}$ \\
\hline Media & $64(81.0)^{\mathrm{a}}$ & $53(66.3)^{\mathrm{a}}$ \\
\hline History & - & $10(12.5)^{\mathrm{a}}$ \\
\hline Personal observation and fish farming experience & - & $5(6.3)^{\mathrm{a}}$ \\
\hline Workshop/studies & $79(100.0)$ & $80(100.0)$ \\
\hline Total & &
\end{tabular}

Source: Authors Computed Field Survey

${ }^{\mathrm{a}}$ Multiple responses 
movement of the fish in the pond; sudden suffocation/floating of fish and death; low oxygen; extreme cold during winter; increase rate of fish mortality; weather change; negative change in fish feeding habit; observable differences in weather temperature; breeding time changes as the weather changes; outbreak of diseases that affect the fish resulting into fish death; sudden death of fish without reasons; change in climate in Europe; appearance of disease; increase humidity; and extreme temperature. While in Nigeria, change in raining pattern and hot temperature; pollution of air; observation of weather change; reduction in water level; negative change in fish feeding habit; flood; present of climate that is affecting hatchery; and changes in fish habit were the observed environmental changes in aquaculture practice in the country.

The research presented the evidences that there were similarities and disparities in environmental changes manifestations in both countries. The level of environmental changes' awareness of the respondents in both countries might be as a result of their level of education (Table 2). Education gave them edge on the changes that are occurring in their environment either positively or otherwise. It implies that respondents in both countries are acquaintance with the changes in their environments (Maddison 2007; Nhemachena et al. 2014). Respondents' multiple responses on other means of environmental changes' awareness might not be unlikely from the global climate change program going round the world because it has brought much anxiety to all countries of the world, hence, the multiple responses.

\section{Environmental Changes Parameters in the Study Areas}

Some environmental parameters such as temperature, rainfall, wind speed, solar radiation, waves and tides, and relative humidity were further considered in the study to ascertain their effect on aquaculture practice and production in both countries. The result revealed that $99 \%$ of the fish farmers in Egypt were aware of the change in environment as a result of temperature. Sixty-three percent ascertained that rainfall pattern and volume has also changed in the country. Fifty-four percent believed that there are changes in the environment as a result of the change in wind speed. Also, $61 \%$ perceived that the change in solar radiation has affected the environment and impacted their fish production. Waves and tides are other environmental parameters that $18 \%$ of the fish farmers in Egypt perceive it change and effect on fish production. Also, $92 \%$ of the respondents further ascertained the fact that changes in relative humidity have impacted their fish production.

In Nigeria, $96 \%$ of the respondents ascertained that temperature change is an environmental factor that affects their fish production in the country. Ninety-four percent perceived change in rainfall pattern and volume, $56 \%$ perceived change in wind speed, $81 \%$ perceived change in solar radiation, and $54 \%$ perceived change in waves and tides, while $81 \%$ also perceived change in relative humidity as environmental factors that have change in recent years (Fig. 3 and Table 4).

The FGD revealed the effects of these environmental parameters on fish production in both countries. Death of fish/mortality; reduction in fish production/growth rate; frozen of fish in winter/low temperature; rise in cost of inputs; and weakness/ low appetite in fish were observed in Egypt. Some of the measures taken by the fish 


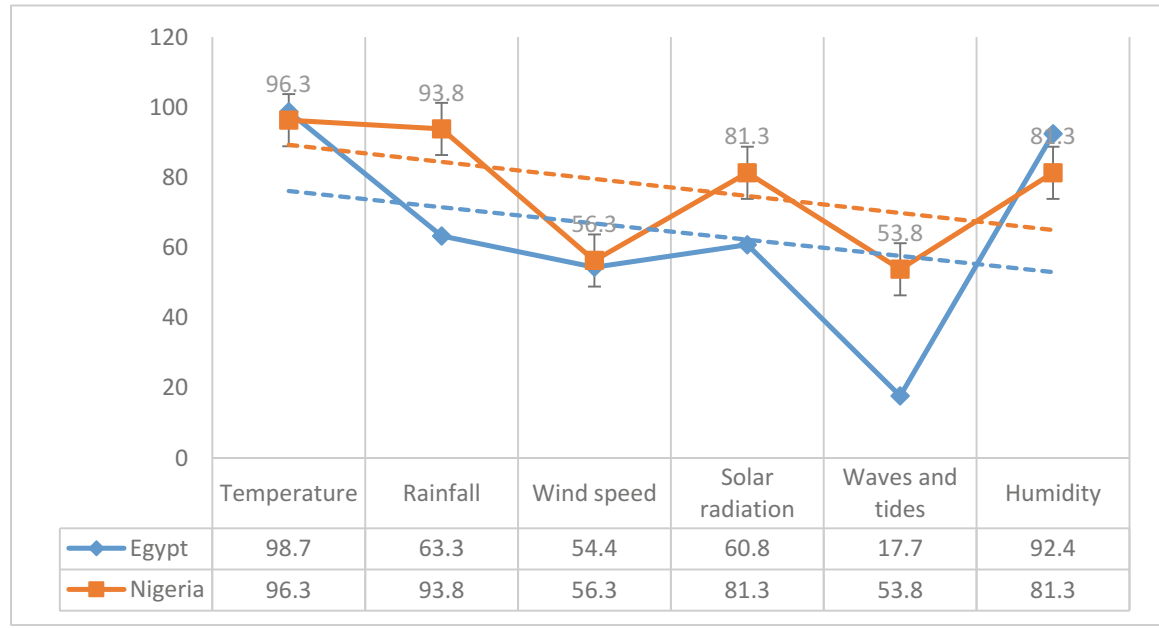

Fig. 3 Environmental changes parameters in the study areas. (Source: Authors Computed Field Survey)

farmers to alleviate the adverse effect of the environmental changes were to improve their management practices and also change their production season as the environment is changing. The effects on aquaculture as expressed by the fish farmers in Nigeria were as follows: low fish production; low feeding in fish; reduction in fish growth rate; more stress for farmers; color of water changes; flooding; and death of fish. Based on the Focus Group Discussion (FGD), the following measures were adopted by the fish farmers in Nigeria change feeding formula/pattern and time, low stocking, pumping or alternative water sources, constant change of water, study/ observe the weather before feeding, minimize feeding in the morning and more in the evening, stop stocking, freshwater and good feeding, removing fish to the other ponds and applying alternative means.

\section{Critical Issues on the Study}

Change in fish production in recent years in the study areas: Change here means positive or negative, increase/decrease, and adverse/mild depending on the previous position of operation of the fish farms/farmers. In Egypt, $96 \%$ confirmed that there has been change in fish production in recent years. This might have been to the various problems such as change in climatic factors which have direct impacts on fish production and pollution of water to the fish farms (agricultural drainage water). The chapter reveals that, climate change affects and impacts agricultural crops, the end users of the irrigated water will suffer directly or indirectly from the effects. Policy makers should look into the plight of the fish farmers in the country and make available use of other means of water to aquaculture. In the contest of Nigeria, the fish farmers $(71 \%)$ did not affirm any serious problems during the course of this study. The reason might be to the fact that aquaculture is still at a promising stage which is best described as the first stage of production (stage 1) where there are still increasing rate of returns (IRR). 
Table 5 Critical issues

\begin{tabular}{|c|c|c|}
\hline \multirow[b]{2}{*}{ Parameters } & Egypt & Nigeria \\
\hline & Frequency $(\%)$ & Frequency $(\%)$ \\
\hline \multicolumn{3}{|c|}{ Has there been any change in fish production in recent years } \\
\hline Yes & $60(95.9)$ & $23(28.75)$ \\
\hline No & $19(24.1)$ & $57(71.25)$ \\
\hline Total & $79(100.0)$ & $80(100.0)$ \\
\hline \multicolumn{3}{|c|}{ Does your fish production meet the demand of the consumers } \\
\hline Yes & $35(44.3)$ & $44(55.0)$ \\
\hline No & $44(65.7)$ & $36(45.0)$ \\
\hline Total & $79(100.0)$ & $80(100.0)$ \\
\hline \multicolumn{3}{|c|}{ Major challenges faced in fish farming } \\
\hline Finance & - & $43(53.75)$ \\
\hline Labor/man power & - & $14(17.5)$ \\
\hline Fish feed cost and other inputs & $27(34.2)$ & $6(7.5)$ \\
\hline Water shortage/water quality & $32(40.5)$ & $11(13.75)$ \\
\hline Fish disease & $20(25.3)$ & - \\
\hline Vices (thief and flood) & - & $6(7.5)$ \\
\hline Total & $79(100.0)$ & $80(100.0)$ \\
\hline \multicolumn{3}{|c|}{ Do you belong to any cooperative society } \\
\hline Yes & $6(7.6)$ & $17(21.25)$ \\
\hline No & $75(92.4)$ & $63(78.75)$ \\
\hline Total & $79(100.0)$ & $80(100.0)$ \\
\hline \multicolumn{3}{|c|}{ Do you have access to extension agents } \\
\hline Yes & $17(21.5)$ & $8(10.0)$ \\
\hline No & $62(78.5)$ & $72(90.0)$ \\
\hline Total & $79(100.0)$ & $80(100.0)$ \\
\hline
\end{tabular}

Source: Authors Computed Field Survey

Other critical issues observed from the study as presented in Table 5. Most of the respondents (92\% in Egypt and $79 \%$ in Nigeria) do not belong to any cooperative society. Bearing in mind the numerous advantages of belonging to a group, unlike in other section of agriculture, e.g., the Cocoa Farmers Association in Nigeria. In addition, the fish farmers in both countries were deprived of the benefits of the extension agents as revealed by the results of the study: Egypt $76 \%$ while Nigeria $90 \%$. These issues were observed as critical; hence, urgent or future attention should be provided in order to protect the future strides of aquaculture in both countries.

Major challenges faced in aquaculture in the study areas: The cost of fish feeds and other inputs contributed to the challenges facing aquaculture; $34 \%$ of the fish famers established this fact. The result buttressed the dependence on private input suppliers who supplied most of the fish farmers on credit and later get all the gains/ profit of the fish farmers; hence, the fish farmers have no say in his farm. That is why most of the fish farmers wanted to quit fish business in Egypt. Forty-one percent were facing water problems; this has to do with the agricultural drainage that they were using, and many of them were not comfortable but have no choice because it is the entitled water for aquaculture in the country. Twenty-five percent were faced with 


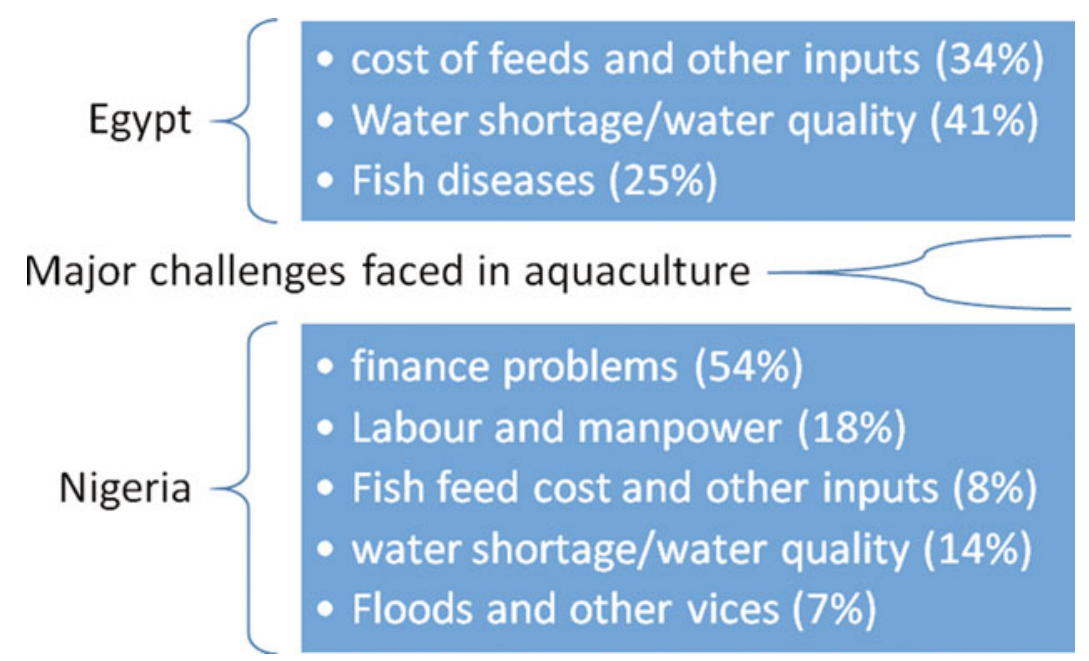

Schematic 1 Major challenges faced in aquaculture in the study areas

fish disease problems. This suggests urgent call for policy makers for intervention. Finance is the major problem facing aquaculture in Nigeria. Most of the respondents (54\%) confirmed that finance is the major challenge unlike in Egypt where water is the major delinquent (Schematic 1).

\section{Conclusion and Recommendations}

The research revealed that there were similarities and disparities in environmental changes indications in Egypt and Nigeria. Though the level of environmental changes awareness of the respondents in both countries varies, the fish farmers were aware of the environmental changes and its impacts on aquaculture. Aquaculture is an age-old practice in Egypt; however it is still contributing immensely to the country's GDP, employment, and food security as it is doing relatively in most countries and is significant to the economic, livelihood, and nutritional welfare of the population. Conversely, Nigeria's aquaculture has the potential to contribute to both food security and economic development of the country, but it is still in a promising business. Efforts should be geared to address the critical issues such as climate change and other environmental factors that affect aquaculture practice in Nigeria. Continental and regional integration of aquaculture practices should be encouraged in Nigeria and other parts of Africa.

\section{References}

Adeleke ML (2013) Socioeconomic characteristics of the artisanal fisherfolks in the coastal region of Ondo State, Nigeria. J Econ Sustain Dev 4(2):2013133. www.iiste.org. ISSN 2222-1700 (Paper) ISSN 2222-2855 (Online). 
Adeleke ML, Balogun AA (2013) Occurrence of climate change and its effects on the fishing activities in the coastal region of Ondo State, Nigeria. Int J Dev Econ Sustain 1(1):1-13

Adeleke ML, Fagbenro OA (2013) Livelihood diversification and operational techniques of the artisanal fisherfolks in the coastal region of Ondo State, Nigeria. Int J Innov Res Dev 2(1):262-273

Adeleke ML, Matthias W (2017) Chapter 13: Adaptation of the artisanal fisher folks to climate change in the coastal region of Ondo State, Nigeria. In: Leal Filho W (ed) Innovation in climate change adaptation, climate change management. Springer, Cham, pp 177-193. https://doi.org/10.1007/978-3-319-25814-0_13

FAO (2000) Fishery country profile, Nigeria. FID/CP/NIR Rev. 4. Food and Agriculture Organization of the United Nations, Rome

FAO (2010) National Aquaculture Sector Overview. Egypt. National Aquaculture Sector Overview fact sheets. Text by Salem AM, Saleh MA In: FAO Fisheries and Aquaculture Department [online], Rome. Updated 16 Nov 2010 (cited 17 Apr 2015). http://www.fao.org/fishery/ countrysector/naso_egypt/en

FAO (2012) The state of world fisheries and aquaculture 2012. FAO, Rome

Food and Agricultural Organisation FAO (2016) The state of world fisheries and aquaculture 2016. Contributing to food security and nutrition for all. Rome. $200 \mathrm{pp}$

French GT, Awosika LF, Ibe CE (1995) Sea level rise and Nigeria: potential impacts and consequences. J Coast Res Spec Issue 14:224-242

GAINS Reports (2015) The state and development of aquaculture in Egypt. https://gain.fas.usda. gov/.../The\%20State\%20and\%20Development\%20of\%20Aquacu.... Nov 6, 2016

Jhingran VG (1987) Lectures at ARAC for the Senior Aquaculturists course. Nigerian Institute for Oceanography and Marine Research Project RAF/82/009

Maddison D (2007) The perception of and adaptation to climate change in Africa. Policy research working paper 4308. The World Bank, Development Research Group, Sustainable Rural and Urban Development Team, Washington, DC

Nhemachena C, Mano R, Mudombi S, Muwanigwa V (2014) Perceptions on climate change and its impact on livelihoods in Hwange district, Zimbabwe. Jàmbá J Disaster Risk Stud 6(1):123. https://doi.org/10.4102/jamba.v6i1.123

Olufayo MO (2012) The gender roles of women in aquaculture and food security in nigeria. IIFET 2012 Tanzania Proceedings

Sumaila UR, Christophe B, Alice T (2014) Fishing for the future: trends and issues in global fisheries trade. December 2014

Worldometers (2017) Elaboration of data by United Nations, Department of Economic and Social Affairs, Population Division. World population prospects: 2017. www.worldometers.info

World Bank (2013) The Fish to 2030: Prospect for Fisheries and Aquaculture World Bank Report Number 83177-GLB (December 2013)

Open Access This chapter is licensed under the terms of the Creative Commons Attribution 4.0 International License (http://creativecommons.org/licenses/by/4.0/), which permits use, sharing, adaptation, distribution and reproduction in any medium or format, as long as you give appropriate credit to the original author(s) and the source, provide a link to the Creative Commons license and indicate if changes were made.

The images or other third party material in this chapter are included in the chapter's Creative Commons license, unless indicated otherwise in a credit line to the material. If material is not included in the chapter's Creative Commons license and your intended use is not permitted by statutory regulation or exceeds the permitted use, you will need to obtain permission directly from the copyright holder.



